\title{
Using the politicized institutional analysis and development framework to analyze (adaptive) comanagement: farming and water resources in England
}

\author{
Luke Whaley $^{1}$ and Edward $K$. Weatherhead ${ }^{2}$
}

\begin{abstract}
The challenge of managing water resources in England is becoming increasingly complex and uncertain, a situation reflected in many countries around the world. Cooperative and participatory forms of governance are now seen as one way of addressing this challenge. We investigated this assertion by focusing on five farmer irrigator groups in the low-lying east of England. The groups' relationship with water resources management was interpreted through the lens of comanagement, which over the past decade has increasingly merged with the field of adaptive management and related concepts that derive from resilience thinking and complex adaptive systems theory. Working within a critical realist paradigm, our analysis was guided by the politicized institutional analysis and development (IAD) framework. Two previous studies concerned with the broader context surrounding farming and water governance in lowland England revealed low levels of trust between farmers, and between farmers and water managers, as well as a power dynamic that stands in the way of farmer cooperation and participation. Within this context, our findings pointed to a number of mechanisms and structural conditions that appear to generate or facilitate comanagement. Of these, institution building through the specific group strategy of adopting a company structure and the "stationarity" of the resource group members extract from were seen to be the most crucial. These and other key findings were used to inform a discussion of farming and water resources management in England going forward. In doing so, we also reflected on the relationship between comanagement and market-based approaches to managing water resources. Beyond this, the research serves as a practical demonstration of how the politicized IAD framework can be used to analyze potential (adaptive) comanagement situations and the related benefits. The analysis complements a previous submission to this journal, in which we discussed the relationship between the framework and (adaptive) comanagement from a theoretical and methodological perspective.
\end{abstract}

Key Words: adaptive comanagement; comanagement; England; farming; politicized institutional analysis and development framework; water resources

\section{INTRODUCTION}

As a concept, comanagement provides a useful lens through which to interpret cooperation and participation in natural resource governance. Not least, it draws attention to key features of the process of developing joint management procedures, including trust, power sharing, and institution building (Pinkerton 1989a, Plummer and Armitage 2007, Berkes 2009). The adaptive turn in comanagement has provided further advances and has deepened our understanding of human-environment relations through its focus on concepts, such as social learning, and its appreciation of the inherent complexity and uncertainty of coupled socialecological systems (Folke et al. 2005, Plummer and Fitzgibbon 2007, Armitage et al. 2009). These developments have shone the spotlight on comanagement as a way of enhancing system resilience and adaptive capacity if it evolves to become adaptive comanagement (Folke 2003, Olsson et al. 2004a, Moberg and Galaz 2005, Armitage et al. 2007), traits that will only become more important as the effects of climate change, a shifting demography, and changing lifestyle preferences continue to challenge the sustainability of natural resource governance (United Nations Environment Programme 2012). (Note: Our use of the term "comanagement" encompasses the concept as originally conceived and its adaptive counterpart, i.e., "adaptive comanagement," in which the latter is seen to be an evolutionary development of the former [Berkes 2009]).

However, despite the contributions that the field of comanagement has made to environmental and natural resource governance, some aspects of the concept remain less well explored. In particular, comanagement research has tended to focus on developing-country contexts or on indigenous communities attempting to secure more substantive property rights claims to natural resources in developed countries. Far fewer studies have explored comanagement in situations in which the actors involved are economically driven and strongly embedded in capitalist systems of production. Furthermore, despite theoretical discussions in the literature (Rose 2002, Tietenberg 2002), very few studies have concerned themselves with the relationship between comanagement and market-based forms of natural resource management.

Beyond these considerations, two methodological issues tend to challenge analyses of comanagement (Whaley and Weatherhead 2014). The first concerns the cross-disciplinary nature of the subject, in which comanagement's traditional social base in commons theory and related fields has in more recent times been complemented by resilience thinking, which has its roots in the natural sciences. The second and perhaps more significant issue relates to the fact that the vast majority of comanagement research focuses on and works toward the development of the normative concepts associated with the subject. In contrast to this, far fewer studies adopt critical forms of analysis to investigate these concepts. With respect to work on social resilience and natural resource management, Wilson (2010) observes that those studies that do adopt a critical approach tend not to exhibit the same rigor as studies that proceed along more normative lines.

${ }^{1}$ Department of Geography, Kings College London, ${ }^{2}$ Cranfield Water Science Institute, Cranfield University 
We offer a contribution to these relatively underdeveloped aspects of comanagement theory and method. We address the theoretical considerations through an analysis of farmer irrigator groups, known as "water abstractor groups," in England. We explore the potential for these collaborations to comanage water resources in conjunction with statutory water managers by identifying key "factors of success" and deeper causal "mechanisms" that appear to generate comanagement. The research comes at a time when the UK government is looking to instigate a more fluid system of water rights trading in England. This provides an opportunity to consider the contribution of abstractor groups to the comanagement of water resources within a market-based context. To guide our analysis, we have adopted a version of the institutional analysis and development (IAD) framework, originally developed by Elinor Ostrom and her colleagues (Kiser and Ostrom 1982, Ostrom 2005, 2011) but that has been modified by Clement (2010) to incorporate a critical consideration of the role of power in natural resource governance. In an earlier study published in this journal (Whaley and Weatherhead 2014), we discussed the suitability of applying this framework to studies of (adaptive) comanagement because of the way in which it is able to address the methodological issues outlined previously. In particular, the politicized IAD framework facilitates a structured and consistent approach to analyzing the "many faces of comanagement" (Berkes 2007, 2009), while advocating for a range of analytical methods designed to provide an integrated and critical understanding of the normative concepts associated with comanagement theory.

We therefore provide an opportunity to move beyond our initial theoretical discussion of the relationship between (adaptive) comanagement and the politicized IAD framework and to demonstrate its applicability from a practical perspective. Our analysis represents the culmination of a research program investigating farmer cooperation and participation in English water governance, which centers on the adoption of the politicized IAD framework. Therefore, the analysis also provides insights into issues currently affecting water management in England. Moreover, it is likely that our findings are of relevance to those attempting to establish comanagement processes in other developed-country contexts with similar conditions.

\section{WATER ABSTRACTOR GROUPS IN ENGLAND}

Unlike many other countries, where agriculture is often the dominant water use, in England irrigation only accounts for approximately $1.5 \%$ of the total volume of water abstracted annually. It is used to supply high-value crops on a land area of roughly 150,000 ha (Woods 2000 , Weatherhead 2006). Nonetheless, in agriculturally intensive regions like the low-lying eastern counties of East Anglia and Lincolnshire, irrigation can account for up to $70 \%$ of water abstracted in some catchments during the summer months (Holman and Trawick 2011).

In these areas, pressure on water resources from agriculture and other uses can sometimes be intense. Confounding this issue, studies by the Environment Agency (EA), the regulating body in charge of managing England's water environment, suggest that water resources across England will become more stressed in the future as a result of "a growing population, increasing demand for water and a changing climate," and that this will result in less water for agriculture (EA 2013:8). For example, an EA report notes that climate change is "likely to alter the water cycle [in England] significantly in the future. The amount and distribution of rainfall will change ... This will affect water availability to support water dependent species and habitats and the availability of water for society and economic growth" (EA 2012:19). The government's response to these challenges has been to consult on changes to the water licensing system, with a focus on reforming it so as to introduce a more fluid system of water rights trading. Although water license trading is technically possible in England and Wales, to date very few trades have taken place because of a number of barriers, among them perceived institutional shortcomings (EA/ Ofwat 2008a).

In reaction to developments in water and environmental regulation that placed new boundaries on water use in agriculture, since the 1990 s a number of farmer water abstractor groups have formed, with the general aim of defending their rights to access a "fair share of water." Over time, however, it has become clear that acting collectively brings additional benefits, both to the members of the group and to the government. Leathes et al. (2008) discuss the institutional capacity of four of these groups to defend their rights to abstract water for irrigation. Beyond this rather insular function, the authors also ask whether there is a role for abstractor groups in water management more generally. The role of abstractor groups in water management is also a question that has not escaped the attention of the EA, which, for example, finds it easier to deal with a coherent group than with numerous individuals (Knox et al. [date unknown]).

The comanagement literature suggests that one area of interest could be the role of abstractor groups in any future water market. They might act much like a trading broker by lowering transaction costs between potential buyers and sellers. Thus, Rose (2002) has considered how communities and user groups could become liberalized by employing a tradable permits approach, as a way of allocating natural resources among themselves. This observation is supported by Tietenberg (2002), who discusses how common pool resources such as water are actually well suited to market-oriented comanagement arrangements.

Although at present only a small number of abstractor groups exist, the likelihood that access to water will become more variable and less secure in the future (EA 2012) suggests that further groups will form in response to a growing number of challenges to irrigated agriculture, particularly in those catchments where water is scarce. This point reinforces the need to understand how these groups may play a role in water resources management in the future.

\section{METHODOLOGY}

The research is situated within a critical realist paradigm (Bhaskar 1975, 1979, Archer et al. 1998). Broadly speaking, critical realism combines a realist ontology with an interpretivist epistemology (Easton 2010). From this perspective, although a world, both physical and social, exists independently of the minds of humans, knowledge of this reality "is filtered through language and concepts that are relative and changeable in time and space" (Danermark et al. 2002:39). Furthermore, reality has ontological depth (Bhaskar 1975). That is, the events we witness in the world are generated by structures and mechanisms operating at a deeper ontological level, and so it is often not possible to observe them directly. Thus, for the realist researcher, the central aim of science is to identify the mechanisms that generate observable events or outcomes of interest within a given context (Danermark et al. 2002). We will discuss this search for mechanisms subsequently. 
We adopted an embedded multiple case study approach (Yin 2009) to analyze the structure and function of 5 farmer water abstractor groups in England. The research employed the politicized IAD framework (Clement 2010, Whaley and Weatherhead 2014) to guide the various strands of the analysis, in which in total data were sourced from 25 semistructured interviews with farmers and governmental and nongovernmental water managers; 2 focus groups with farmers in catchments to the east and west of the country; an analysis of primary and secondary documents relating to water policy and the development of farming and water management dating from World War II until the present day; and a literature review. We incorporate and build on the findings from 2 separate analyses (Whaley and Weatherhead 2015a, 2015b), as described subsequently.

\section{Five case studies}

The 5 water abstractor groups we analyzed are located in the lowlying, and generally drier, east of England (Fig. 1). Our intention was to include the same 4 groups previously analyzed by Leathes et al. (2008). After contacting representatives from each of these groups, we found one of them, the North Northumbrian Water Abstractor Group, was no longer fully operational. The remaining 3 are the Broadlands Agricultural Water Abstractor Group (BAWAG), which formed in 1997 and comprises roughly 180 farmer members and 20-30 corporate members; East Suffolk Water Abstractor Group (ESWAG), which consists of approximately 80 members and which also formed in 1997; and Lincoln Water Transfer Limited (LWT), which officially formed sometime during the late 1990s.

Fig. 1. Map of England and Wales showing location of the five water abstractor groups included in the study. Blue shading represents areas under the management of internal drainage boards. Adapted from Venables et al. [date unknown]. BAWAG, Broadlands Agricultural Water Abstractor Group; ESWAG, East Suffolk Water Abstractor Group; LWT, Lincoln Water Transfer.

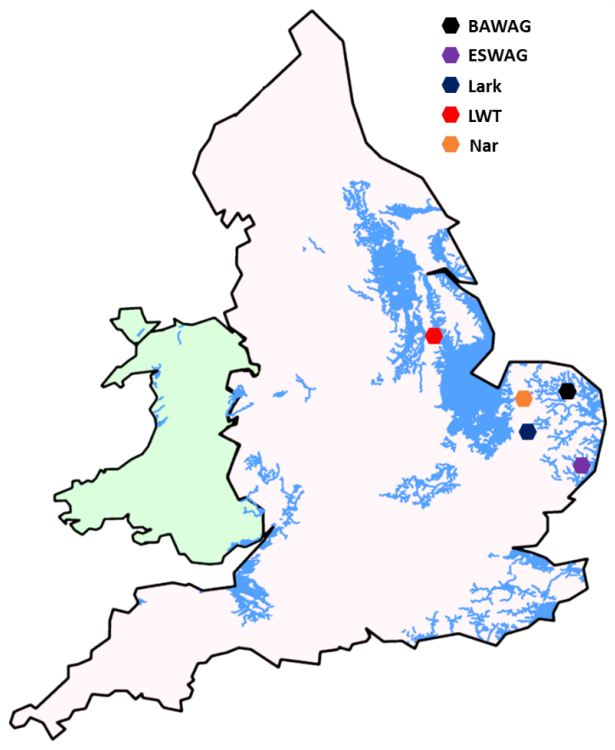

LWT initially consisted of 19 members but over time has been reduced to 14 as several members have left and new members have joined. An initial scoping exercise of all the case studies revealed that LWT appears to be somewhat different from the other groups with respect to its involvement in water resources comanagement. As will become apparent subsequently, LWT served as an "extreme case study," allowing us to explore certain factors that give rise to comanagement in its "purer" form (Danermark et al. 2002).

Alongside these 3 groups, i.e., BAWAG, ESWAG, and LWT, we included 2 more. These are the Lark group, which is the oldest abstractor group in England, having formed in 1991 and consisting of roughly 80 members, of which approximately 50 hold significant water licenses; and the Nar group, a nascent organization comprising roughly 30 farm businesses that formed on the River Nar during 2011. These 5 groups account for the vast majority, if not all, of the active water abstractor groups in England (Knox et al. [date unknown]).

\section{Applying the politicized institutional analysis and development framework}

We analyzed the structure and function of the five water abstractor groups and their contribution to seven broad comanagement activities (Table 1) using the politicized IAD framework (Fig. 2). The comanagement activities are adopted from Pinkerton (1989b). Our approach to employing the framework follows the process detailed in Whaley and Weatherhead (2014), which allowed us to critically analyze normative comanagement concepts within the context of the specific case histories of the five abstractor groups. The following steps summarize this process: (1) define the relevant action situations; (2) analyze the components of each action situation, including outcomes; (3) analyze the shared strategies that individuals and groups adopted within the actions situations; (4) evaluate interactions and outcomes; (5) investigate the five sets of exogenous variables and analyze the ways in which they structure the action situations; (6) infer generative mechanisms and structural conditions from the relevant factors identified in the previous step; and (7) consider future interactions and outcomes given certain changes to the structure of action situations.

Table 1. Seven comanagement activities. Adapted from (Pinkerton 1989b).

Comanagement Activities

1 Data gathering and analysis

2 Logistical decisions such as who can abstract water and when

3 Water allocation decisions

4 Protection of resource from environmental damage

5 Enforcement of regulations

6 Enhancement and long-term planning

7 Broad policy decision making

With respect to step 1, an "action situation" relates to the social space "where individuals interact, exchange goods and services, solve problems, dominate one another, and fight (among the many things that individuals do in action situations)"(Ostrom 2011:11). 
Actions situations are composed of seven working components (Fig. 3), where there are "participants" who take up various "positions," and where any given position allows the participants to undertake certain "actions" that are dependent on how much "information" they possess about each available action, how actions are linked to "potential outcomes," the degree of "control" individuals exercise over these outcomes, and the "costs and benefits" they assign to them (Ostrom 1990). For each of the five groups, the action situations we identified pertained both to different levels of governance, such as operational and collectivechoice levels, and organization, such as interorganizational and intragroup dynamics.

Fig. 2. The politicized institutional analysis and development framework, with the two variables that have been analyzed in separate studies shaded in gray. Adapted from Clement (2010).

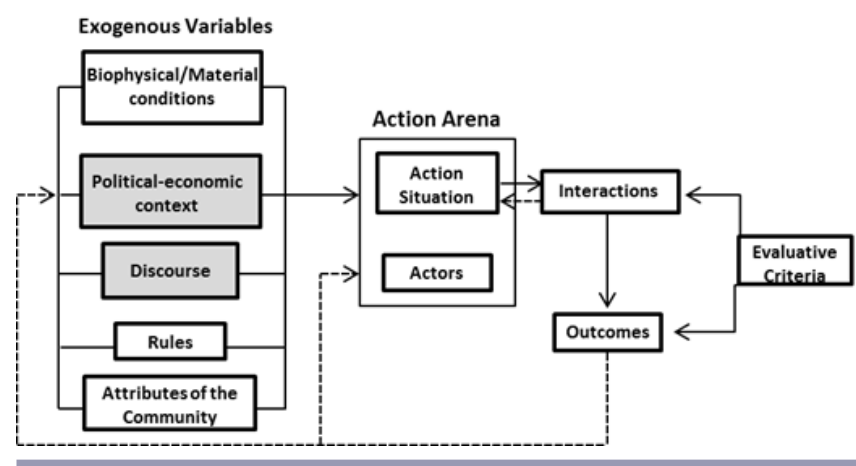

Fig. 3. The action situation of the institutional analysis and development framework. Adapted from Ostrom (2005).

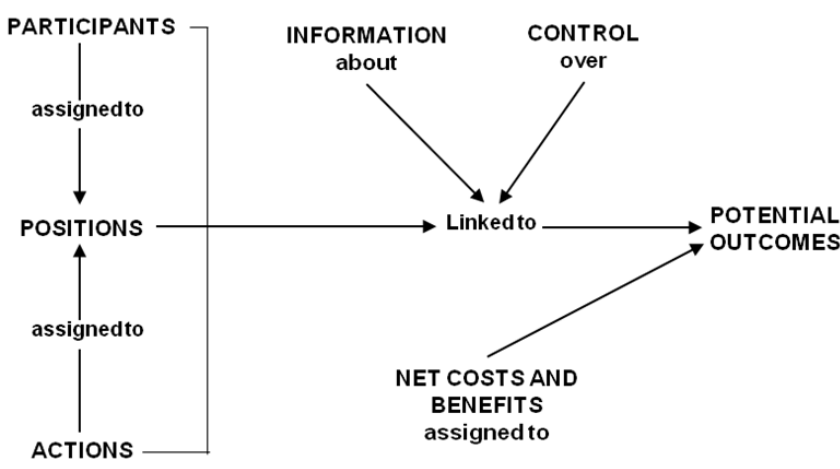

With respect to step 5, we considered how the five sets of exogenous variables structure both the broader context in which all five groups are operating, where this relates to a geographic region encompassing the low-lying areas of southern and eastern England, and each of the various action situations pertaining to the different case studies, i.e., local structural conditions. The forms of the analyses we undertook for each set of variables, as well as the focus of these analyses, were guided by the relationship between the sets of exogenous variables and the seven components of the action situation in question. For example, the discourse element of the framework most directly influences the position component of the action situation (Clement 2010). This led us to consider positioning theory as a relevant approach when analyzing the discourse of the farmers in the study. Alternatively, the rules element of the framework directly affects all seven components of the action situation (Ostrom 2005), and our analysis therefore sought to identify relevant rules that accorded with the seven categories of rules that stem from this relationship, namely, boundary, position, choice, aggregation, information, payoff, and scope rules (Ostrom 2005).

Considering the broader context, two of the sets of exogenous variables of the politicized IAD framework, relating to the "political-economic" and "discourse" elements (see Fig. 2), were analyzed in separate studies. In the first study (Whaley and Weatherhead 2015b), we employed a political economy analysis of farming and water governance in England for a time period dating from World War II until the present day. The research was based on an analysis of government documents and other primary texts and an extensive review of secondary sources. We adopted an approach known as the "power cube" (Gaventa 2005, 2006), which explicitly structures the analysis of power along the three dimensions of a theoretical cube. These dimensions consist of the following: (1) the different forms that power takes, i.e., visible, hidden, and invisible (sensu Lukes 1974); (2) the types of spaces that power creates and operates within, i.e., closed, invited, and claimed; and (3) the levels at which power operates, e.g., local, national, and international. Doing so revealed how different forms of power, operating in different types of spaces and at different levels of governance, have come to shape the current dynamic among farmers, as well as between farmers and water managers, in England.

In the second study (Whaley and Weatherhead 2015a), we investigated the discourse element of the framework by employing 2 concepts from critical discursive psychology (Edley 2001) to analyze the ways in which irrigators in England talk about water management, water managers, and the water environment. Data consisted of 20 interviews and 2 focus groups, in which interviewees were members of water abstractor groups, whereas the focus groups comprised farmers from 2 separate catchments who were considering forming an abstractor group. The 2 analytical concepts we utilized were interpretive repertoires and subject positions.

An interpretive repertoire shares much in common with the more well-known concept of a discourse but is generally seen to be smaller and less overbearing. In effect, interpretive repertoires are ensembles of ideas, categories, and concepts "used for characterizing and evaluating actions, events and other phenomena," in which "often a repertoire will be organized around specific metaphors and figures of speech" (Potter and Wetherell 1987:149). Subject positions refer to the positions people negotiate and assign to themselves and others during the course of social interaction (Davies and Harré 1990, Harré et al. 2009). Interpretive repertoires can therefore be thought of as different story lines or versions of events, and it is within these story lines that agents are positioned. To this extent, interpretive repertoires and subject positions are bound up with the negotiation of power, as some repertoires become dominant and solidify into distinct institutional structures and organizational practices (Hajer 1995). In the second study, the subject positions of interest relate to farmers and the various actors involved in water governance, as well as the water environment itself. 
Variables relating to the political-economic and discourse categories of the framework most directly affect the position element of the action situation (Fig. 3). They also shape the values, norms, and preferences of participants in these situations (see Whaley and Weatherhead 2014). As a result, the findings from these two studies have a strong bearing on the behavior of participants in the action situations of interest. Both analyses served to highlight how context, power, and levels of trust fundamentally influence the ability of farmers to comanage water resources in England. A discussion of the findings of each study is provided in Results.

As noted previously, in keeping with a critical realist approach (Bhaskar 1975, 1979, Sayer 1992, Danermark et al. 2002) a core concern of the research was to identify the deeper causal mechanisms that generate comanagement arrangements between abstractor groups and water managers. It is important to note that the effects of these mechanisms are contextual (Sayer 1992) in that their operation can only be understood in light of both the broader and more local structural conditions we identified when investigating the politicized IAD framework's five sets of exogenous variables. As our results show, LWT proved to be the only case in which a true comanagement arrangement has emerged. It therefore served as an extreme case study (Danermark et al. 2002), in which we used the politicized IAD framework to identify factors of success that appeared to link the LWT group to a comanagement outcome and from which we then made inferences about what these factors suggest either about the presence of local structural conditions or generative mechanisms operating at a deeper, more conceptual level (see Bhaskar 1975). By way of illustration, well-known causal mechanisms in the social sciences literature include the market mechanism, class, and peer group influence. In the comanagement literature, examples of mechanisms might include social learning, problem solving, and trust.

The explanatory power of the structures and mechanisms we identified in the LWT case was decided on by employing two approaches suggested by Danermark et al. (2002), namely, counterfactual thinking and comparative case study approaches. The interactions and outcomes of each case study were evaluated using three related transaction costs, namely, information, organizational, and strategic costs (Imperial 1999). We also evaluated the ways in which the cases did or did not contribute to the overall adaptability, efficiency, and equity of water management, as outlined in Ostrom (2005).

Following the analysis, we considered the implications of our findings for water resources management in England going forward. This involved making assumptions about likely changes to several of the exogenous variables of the politicized IAD framework, and thus the context of water management, in the future. Given the complexity of natural resource management, and of social science work more generally, it is not possible to make strong predictions as to future interactions and outcomes. However, as Polski and Ostrom (1999:24-25) note: "When examining these more open, less constrained situations, a policy analyst is forced to make weaker inferences about patterns of interaction. However, well-informed weak inferences can still provide important policy information." The IAD framework is a powerful tool for making well-informed inferences about the behavior of a system because of the integrated, comprehensive, and context-specific approach it encourages the analyst to adopt (Whaley and Weatherhead 2014).

\section{RESULTS}

First, we provide an overview of the findings of our investigation into the five sets of exogenous variables of the politicized IAD framework as they apply generally to all five case studies. These insights serve to identify relevant aspects of the broader structural conditions within which all five groups currently operate. We summarize the main findings from the the political-economic and discourse analyses, explored in the two previous studies (Whaley and Weatherhead 2015a, 2015b), before considering the remaining three sets of exogenous variables, namely, the biophysical-material world, rules, and the community.

\section{Findings of the political-economic and discourse analyses}

The political economy analysis revealed that the system of industrial agriculture that developed after World War II in England resulted in an occupational identity for lowland farmers that revolves around individualism, competition, and a desire to maximize profit and production, often at the expense of the environment. In part, this sense of identity, or power "within" (VeneKlasen and Miller 2002), appears to have been maintained by the corporate agricultural supply chain and the structure of the global food system, which exert considerable downward pressure on farmers.

Alongside this, two other key findings can be distilled from the analysis. First, despite structural moves in England toward more participatory, cross-scale forms of water governance, government agencies such as the EA continue to exercise power over farmers and other nonstate actors instead of sharing power with them. Second, the relationship between farming and environmental interests is one founded on conflict and dispute and is characterized by a lack of trust. These findings suggest that notions of participation, cooperation, and wider environmental concern are marginal considerations for many farmers in England today, especially in the low-lying east of the country where largescale, mechanized farming dominates (Holderness 1985, Marsden et al. 1993).

The political economy analysis also charted the rise of water abstractor groups, which, as mentioned previously, started to form in the 1990s to defend their rights to abstract water. At the same time, legislation emanating from Europe, influenced by international conferences and conventions, has resulted in greater opportunity for farmers to participate in water management at the local catchment and subcatchment levels. This suggests that there is space for water abstractor groups to undertake a more proactive management role, despite their reactive beginnings. However, the analysis highlighted the difficulty of achieving such an outcome given the barriers identified previously.

The discourse analysis identified three different interpretive repertoires, namely, the "competition," "conflict," and "compromise" repertoires. The competition repertoire was the most dominant of the three, whereas the compromise repertoire was by far the least dominant. The competition repertoire embraces strong business values and takes a utilitarian approach to the water environment. According to this repertoire, farmer cooperation and participation in water governance is only 
considered of any use if it makes sense from an individual business perspective. The conflict repertoire, which is "founded on a logic of opposition and stresses the place of conflict and difference in water resources management," serves to largely obstruct the comanagement process (Whaley and Weatherhead 2015a:808).

On the other hand, the less prominent compromise repertoire provides more scope for farmer cooperation and participation in water governance. This is because it recognizes the value of the wider water environment and views water resources management as "a process of balancing the various needs of the stakeholders who use water" (Whaley and Weatherhead 2015a:811). The analysis highlighted the importance of improving communication between farmers, and between farmers and water managers, to move beyond the competition and conflict repertoires and to instead nurture a more widespread adoption of the compromise repertoire.

As noted in Methodology, each interpretive repertoire has a number of subject positions associated with it that relate to the various actors involved in water governance. One outcome concerning the dominance of the competition and conflict repertoires is attributed to the subject positions both repertoires provide for governmental and nongovernmental water managers, which suggest that relationships between farmers and water managers are characterized in large part by a distinct lack of trust. Because of the importance comanagement places on the development of trust (Olsson et al. 2004a, Folke et al. 2005, Plummer 2006), this represents a significant challenge to partnership building.

Given the findings of the political economy and discourse analyses, we conclude that the dominant norms of the farmers are likely to be those of competition, business operating procedures, conflict, and nonparticipation, and the values they place on water management outcomes will tend to revolve mostly around profit and business independence, success, and professionalism. On the whole, the findings of these two studies would appear to act as a distinct barrier to the emergence of comanagement between abstractor groups and water managers in England.

\section{Biophysical-material, rules, and community variables}

Considering first the biophysical-material element of the framework, a common feature of many catchments with a high proportion of irrigation licenses is the presence of on-farm reservoirs. The biophysical-material world affects what actions are physically possible in an action situation, what outcomes can be produced, how actions are linked to outcomes, and what is contained in participants' information sets (Ostrom 2005). Therefore, having a degree of storage in the system in the form of reservoirs has the potential to significantly affect the internal dynamic of the action situation and the incentives participants face. In the discussion, we will consider the role of on-farm reservoirs in agricultural water management going forward.

Given that England is a country with strongly enforced formal institutions, we have taken the government regulations relating to water management as de facto conditions that participants operate under within the action situations at which we looked. Many of the rules that are of particular relevance relate to the government's water abstraction regime, which is enforced by the
EA; see Ostrom (2005:188-215) for a discussion of the types of rules that structure an action situation. In particular, there is a boundary rule stating that anybody intending to abstract $>20 \mathrm{~m}^{3}$ of water a day must first obtain a license. The license itself contains scope rules detailing how much water a person or business can take, what they can use the water for, where and when they can abstract water, and any minimum flow or level limitations. Breaches of the license conditions may result in financial losses to farmers if they are claimants of the various subsidies available through the EU's Common Agricultural Policy, in which a proportion of the amount normally received can be withheld as a penalty. Continued license transgressions can result in the EA taking legal action through the courts.

Other rules relating to water resources management include section 57 of the Water Resources Act 1991, which states that during periods of water scarcity the EA has the power to halt water abstraction for the purpose of spray irrigation. Furthermore, there are rules allowing abstractors to trade their licenses with one another on a water body, although to date few trades have taken place. In part, this is because of a lack of understanding of how to trade and the time-consuming nature of the process (EA/Ofwat 2008b). However, as we noted previously, now it is the intention of the government to operationalize a more enhanced system of water license trading in England.

Finally, with respect to the community element of the framework, the vast majority of farmers we interviewed were white males between the ages of 40 and 65 . This is unsurprising given that farmers in the United Kingdom are predominantly male, with an average age of 59 (DEFRA 2012).

Having considered the results of our analyses of the broader context according to the politicized IAD framework's five sets of exogenous variables, we discuss the findings from the analyses of the five case studies. As already noted, of these groups, LWT differs substantively from the others in terms of its involvement in the comanagement of water resources. Because of this, we have combined the discussion of the remaining four groups and follow with a more detailed consideration of LWT. However, we shall return to consider all five groups together when identifying the explanatory power of the different mechanisms and key structural conditions that appear to generate or facilitate the development of comanagement in the LWT case.

\section{Analysis of four farmer irrigator groups}

Our analysis confirmed the findings of our initial scoping exercise, namely, that BAWAG, ESWAG, Lark, and Nar abstractor groups contributed relatively little from a comanagement perspective (Fig. 4). Instead, to differing degrees, the central function of these groups is to lobby for farmers' rights to access water. However, despite their lobby focus, it has been noticeable that over time the groups have developed more proactive tendencies. Perhaps the most notable contribution of these groups to water resources comanagement is a shared strategy, adopted by several of them, to volunteer a reduction in their water use during periods of water scarcity. This strategy appears to have been adopted to avoid a section 57 order, as discussed previously, rather than out of any altruistic impulse on behalf of farmers to improve the water resources situation in the catchment as a whole. 
Fig. 4. The combined contribution of the water abstractor groups, i.e., Lark, Broadlands Agricultural Water Abstractor Group, East Suffolk Water Abstractor Group, and Nar, to Pinkerton's seven comanagement activities.

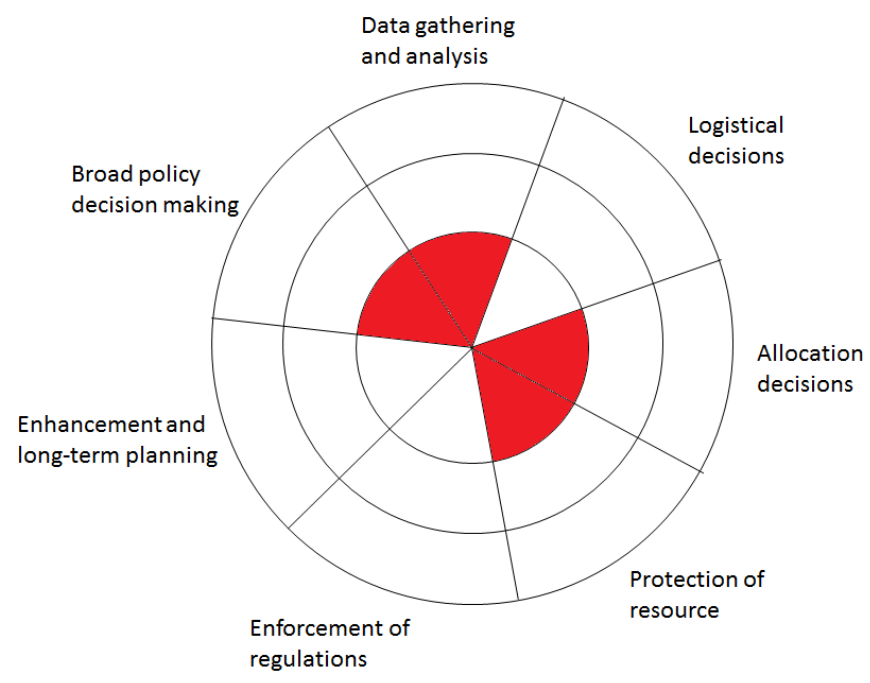

We also observed evidence of groups encouraging water efficiency measures among their membership, conducting resource monitoring, representing farmers in conferences and meetings dealing with broader water policy issues, and commissioning studies to assess resource conditions in some catchments and the value of irrigable agriculture to the local economy. Again, these measures have been adopted largely to improve the groups' ability to effectively lobby for farmers' rights and to increase the benefits they gain from irrigation. This behavior is in keeping with our findings from the political economy and discourse analyses, which, as discussed previously, would suggest that the farmers would tend to act in ways that benefit their own individual (business) interests. There is also evidence that at least two of the groups were facilitating water trading between members, either through advertising of spare water in their periodic newsletters or through face-to-face communication between members at meetings.

An analysis of the information component of the action situation revealed that group members held varying degrees of local timeand-place knowledge, which may contribute to water management decision making. This related to an understanding of the distribution of interests and resources within the catchment, local knowledge of the resource and its history, current and future water requirements, and future business practices that may have an impact on the resource. In contrast, the knowledge held by the regulatory agencies stemmed from a scientific approach to managing water and focused on a better appreciation of the bigger picture of water governance in England. Although staff in these agencies also held a degree of local knowledge, over time this knowledge base has eroded as staff members have retired or have moved on in the many waves of government reorganization.

EA officers also held detailed knowledge about water and environmental regulation, as well as recent or upcoming changes to these regulations. Interestingly, in each case the leader of the abstractor group also held this information to a large degree. In two of the groups, there was a choice rule (again, see Ostrom [2005], for a discussion on the types of rules and their relationship to the action situation of the IAD framework) instructing the leader of the group to remain up-to-date with water legislation and to attend meetings and conferences when necessary. In both these cases, this individual received a salary from the group, primarily to perform this function.

Considering the costs and benefits of abstractor groups from a transaction costs perspective, it is clear that the biggest benefit to water governance has been a reduction in information costs. This is a direct result of enhanced communication channels between farmers, and between farmers and water managers. On the other hand, coordination costs have tended to increase for the farmers involved, particularly in the early stages of group formation. This increase in coordination costs is significant in light of the findings from the political-economic analysis, whereby the prevailing power dynamic serves as a barrier to farmer cooperation and participation in water governance because of demands on time and a central concern with costs and profit. Although we discovered little hard evidence to suggest it occurs, the formation of an abstractor group in a catchment opens the door for a number of strategic costs. These costs relate to the ability of nonmembers in the catchment to free ride on the group's achievements and the potential for groups, or even specific individuals within the groups, to exert power over other participants to achieve purely selfish ends. Given that the four groups in question offer only a minimal contribution to the comanagement activities in Table 1, we do not discuss their relationship to the more general evaluative criteria of adaptability, efficiency, and equity.

\section{The case of Lincoln Water Transfer Limited}

In contrast to the other four water abstractor groups, the LWT group is a clear example of a case in which farmers have selforganized to comanage water resources. Given the generally low levels of trust between participants and the way in which the current power dynamic in England stands in the way of farmer cooperation and participation in water governance, this case represents a notable exception. As a result, it is of much interest to identify the key factors that link the farmers to a comanagement outcome and the causal mechanisms and structural conditions that can be inferred from these factors of success. Before discussing our findings, we provide a brief overview of the comanagement scheme in which LWT participates.

\section{The Lincoln Water Transfer Limited scheme}

The area where the LWT group operates is characterized by a network of drainage ditches from which the members are able to abstract water for irrigation during the growing season. These ditches represent a "ponded" system inasmuch as the water in them tends to stand relatively still, making it significantly easier to manage water levels. The interconnection of the ditches also means that water can be withdrawn at any point in the system. The ditches drain into the oldest canal in England, the Fossdyke Canal, which connects the River Trent with the River Witham. The drainage ditches are managed by an internal drainage board (IDB), which is a body with the jurisdiction to manage water levels in certain low-lying areas of England that are most at risk from flooding; see Fig. 1 for areas where the IDBs operate. The LWT group, which is currently composed of 14 farm businesses 
Table 2. Nine factors contributing to the success of the Lincoln Water Transfer Limited (LWT) comanagement scheme and the structural conditions and generative mechanisms derived from them; displayed in relation to the five sets of exogenous variables of the politicized institutional analysis and development framework and compared with the other four case studies.

\begin{tabular}{|c|c|c|c|c|c|c|c|}
\hline \multirow{2}{*}{$\begin{array}{l}\text { Exogenous } \\
\text { Variable }\end{array}$} & \multirow{2}{*}{$\begin{array}{l}\text { Factors of Success in LWT } \\
\text { Scheme }\end{array}$} & \multirow[t]{2}{*}{ Structural Condition } & \multirow{2}{*}{$\begin{array}{l}\text { Generative } \\
\text { Mechanism }\end{array}$} & \multicolumn{4}{|c|}{ Present in Other Cases? } \\
\hline & & & & $\mathrm{ESWAG}^{\dagger}$ & $\mathrm{BAWAG}^{\dagger}$ & Lark & Nar \\
\hline Rules & Formation of limited company & - & Bonding & Yes & Yes & No & No \\
\hline Rules & $\begin{array}{l}\text { Members' agreement and } \\
\text { protocol }\end{array}$ & - & $\begin{array}{l}\text { Carrot and } \\
\text { stick }\end{array}$ & No & No & No & No \\
\hline Rules & Shared license & - & Bonding & No & No & No & No \\
\hline $\begin{array}{l}\text { Biophysical- } \\
\text { material }\end{array}$ & $\begin{array}{l}\text { Ponded system of drainage } \\
\text { channels }\end{array}$ & Stationarity & - & No & No & No & No \\
\hline $\begin{array}{l}\text { Biophysical- } \\
\text { material }\end{array}$ & Access to additional water & - & Bonding & No & No & No & Yes \\
\hline Community & $\begin{array}{l}\text { Similar race, age, gender, and } \\
\text { profession of group members }\end{array}$ & Homogeneity & - & Yes & Yes & Yes & Yes \\
\hline Community & Small group size & Group size & - & No & No & Yes & Yes \\
\hline Community & Presence of a leader & - & $\begin{array}{l}\text { Bonding and } \\
\text { bridging }\end{array}$ & Yes & Yes & Yes & Yes \\
\hline $\begin{array}{l}\text { Political- } \\
\text { economic }\end{array}$ & $\begin{array}{l}\text { Close relationship between } \\
\text { farmers and } \mathrm{IDB}^{\dagger}\end{array}$ & - & Bridging & No & No & No & No \\
\hline Discourse & $\begin{array}{l}\text { Greater use of "compromise } \\
\text { repertoire" }\end{array}$ & - & Trust & No & No & No & Yes \\
\hline
\end{tabular}

${ }^{\dagger}$ BAWAG, Broadlands Agricultural Water Abstractor Group; ESWAG, East Suffolk Water Abstractor Group; IDB, internal drainage board.

(originally 19), formally came together in the late 1990s after years of attempting to secure additional water for irrigation. A window of opportunity arose when improvements were made to the capacity of a water transfer scheme, i.e., the "Trent-withinAncholme (TWA) scheme," which carried water from the River Trent via the Fossdyke Canal to supply a town farther downstream of the River Witham. With the upgrade to the TWA scheme, it was possible for the group of farmers to request some of this additional capacity being supplied from the Fossdyke Canal to service their own irrigation needs.

The LWT group shares a single abstraction license, which it initially divided up among its members according to predicted water demand. Some or all of each member's license share can then be reallocated within the group either before or during the growing season, as circumstances dictate. Although submissions of unwanted water by members into a central pool, and requests by members to take water from this pool, are managed by the IDB, the group's board of directors has final say on how the water is allocated. This is important in situations in which demand for water from the central pool outstrips supply. In these situations, it appears the board would employ a pro rata approach, in which water is allocated to members requesting additional water in accordance with their overall license share. The group also holds a second shared license. This license allows it to apply for additional water under the TWA scheme when water levels in the network of drainage ditches fall too low to allow for irrigation.

The LWT scheme entails a close working relationship between the abstractor group and the IDB, which has taken on the responsibility of administering the system on behalf of the group, as well as the EA, which is in charge of transferring additional water under the TWA scheme. In order that the IDB can manage water levels accurately, LWT members are required to provide weekly returns detailing their water use in the previous week and an estimation of their water use for the coming week. Over time, the function of the group has evolved. Of particular note, LWT has funded its own program to eliminate the potato brown rot virus, Ralstonia solanacearum, from the watercourses where it abstracts. The status of the group has also meant that its leader is invited to attend meetings, conferences, and workshops relating to water resources management and policy direction in England. Our assessment of the overall contribution that the LWT scheme makes to water resources management is shown in Figure 5.

Fig. 5. The relative contribution of the Lincoln Water Transfer Limited scheme to Pinkerton's seven comanagement activities.

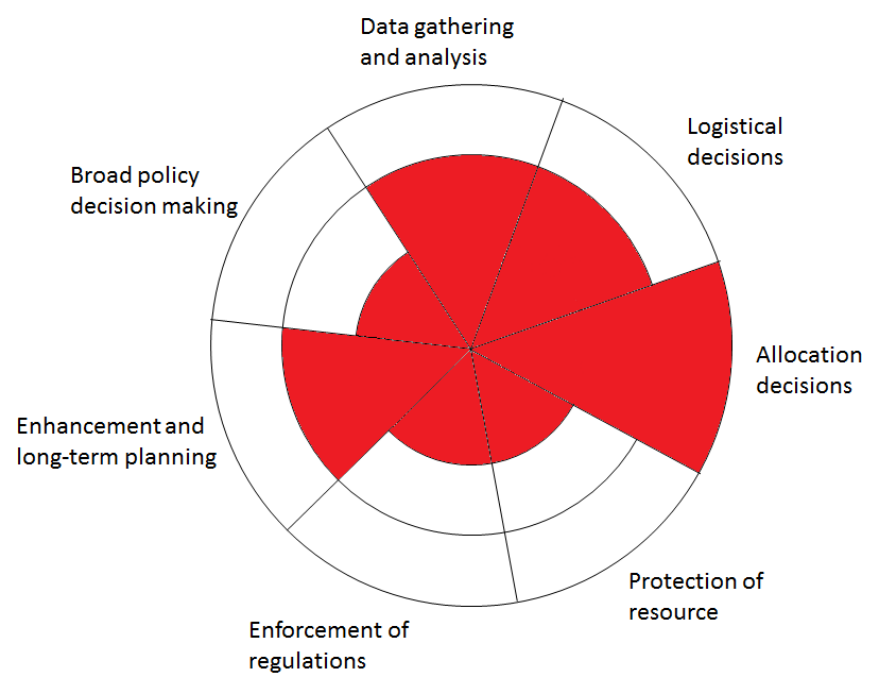


Factors of success, local conditions, and generative mechanisms Using the politicized IAD framework (Fig. 2), we were able to identify a range of factors that appear important to the success of the LWT scheme. We consider these factors of success in relation to the scheme's formation, operation, and evolution. Table 2 displays the various factors, which have been categorized according to their relationship to the exogenous variables of the politicized IAD framework, and whether they were present or absent in the other four case studies. Table 2 also displays whether the factors relate to local structural conditions or whether they imply the activity of causal mechanisms. As discussed in Methodology, by using counterfactual thinking, and by comparing whether these factors of success were present in the other case studies, we were able to more specifically identify those structures and mechanisms that appear to have the most explanatory power.

With one exception, the names of the mechanisms we identify are derived from the comanagement and adaptive comanagement literature. For example, Berkes (2009) suggests that comanagement has a number of different "faces," several of which, such as institution building and trust building, could be considered mechanisms. In recent years, there has also been much attention given to both network theory and the concept of social capital in understanding the emergence and development of comanagement (Plummer 2009). We draw on concepts from this literature, in particular, bonding and bridging capital, to articulate the workings of several of the mechanisms identified.

During the formation of the scheme, a key factor stems from the rules element of the framework, in which the group decided to form a limited company to conduct its affairs. It is clear that adopting a corporate strategy helped the group to overcome the prevailing power dynamic and low levels of trust we identified in the political economy and discourse studies by providing a structure and an operating environment in keeping with the business orientation of modern farming. Furthermore, the very notion of a company appears to have cultural appeal to these farmers, bonding them together through their mutual understanding of and appreciation for it. It also gave the group independent legal status, which greatly assisted with its successful application for the shared water license. The adoption of the shared license, which was not present in any of the other cases, also appears to have triggered a bonding mechanism among group members because, as with the decision to form a company, introducing a shared license brought the farmers together and encouraged collective decision making and action.

Staying with the rules element of the framework, the formation of a private company was accompanied by the drawing up of a legally enforceable members' agreement and protocol that detail members' rights, conduct, commitments, costs, and benefits, as well as punitive measures for rule infringements. Doing this embedded LWT within a macroinstitutional structure that supports the group from both a legalistic and a regulatory perspective, while still providing it with a degree of local autonomy. The protocol also details an operating procedure for internally allocating water among group members. On a general level, the members' agreement and protocol represents a case of institution building at the local level (Pomeroy and Berkes 1997). More specifically, however, we can observe that the specific system of rules devised by the group serves to act both as a carrot and a stick for its members. This is important given the structural conditions we identified previously, which promote individualism, competition, a drive to increase profits, and low levels of trust among the farmers.

On the one hand, the rules devised by the group act as a carrot by giving members the opportunity to flexibly manage their water allocation, thus increasing business profit and security. There are also rules for fiscal equivalence, whereby the benefits accrued by members are consistent with their financial contribution to the workings of the scheme. This point would appear important to these farmers because their strong business orientation infers they are unlikely to want to spend more than they consider fair or to concede any perceived competitive advantage to other members. On the other hand, the rules, which are upheld by English law, also act as a stick. In particular, serious rule infringements on the part of members or a failure on the part of government officials and others to respect the terms of the agreement can result in action being taken in the courts. As can be seen in Table 2, this "carrot-and-stick mechanism" (Fig. 6) is unique to the LWT case study and appears to be crucial in explaining the emergence and development of the comanagement arrangement.

Fig. 6. The carrot-and-stick mechanism.

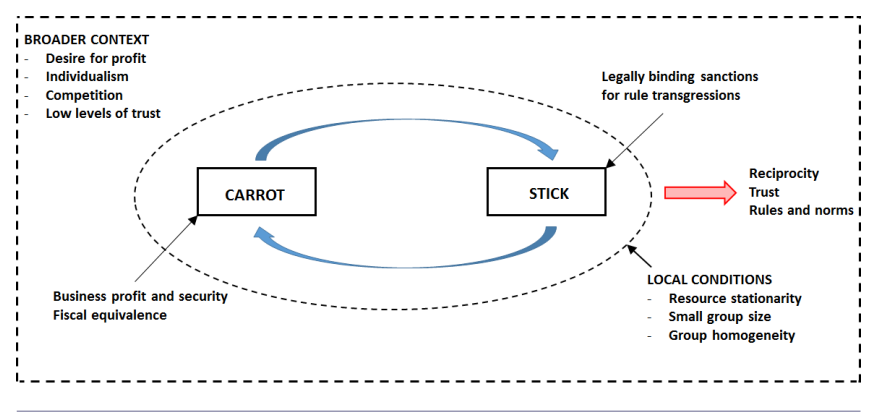

From a biophysical perspective, the key factor to note is the ponded system of drainage ditches that the group abstracts from, which relates to the "stationarity" of the resource. Stationarity refers to the mobility of a natural resource such as water, where the less mobile the resource is, the more stationarity it has (Schlager et al. 1994). As Ostrom et al. (1994:314) discuss, stationarity is an important condition for developing collective action because it "significantly affect[s] appropriators' incentives and capabilities to devise rules because of [its] impact on the type of information available ... [stationarity affects] the level of reliable information and the costs of obtaining information." Stationarity was unique to the LWT case and can be considered a key structural condition that facilitated the action of the various comanagement mechanisms we detail. The ability of the group to secure water over and above its existing allocation was also an important factor because it represents a "plus-sum game," which is known to promote collaboration among water users (Dinar et al. 1997). This access to additional water points to the last of three mutually reinforcing bonding mechanisms, with the other two having already been detailed previously.

From the perspective of the community element of the framework, commons theory suggests that the homogeneity of 
the farmers' identities in terms of age, race, gender, and profession would most likely have assisted group formation (Wade 1987, Ostrom 1990, Baland and Platteau 1996). Another key community factor was the presence of leadership within the group, which took the form of a new farm business in the area with a strong desire to secure additional water for irrigation. The manager of this farm, incentivized by the success of his business, functioned as an "energy center" (Pinkerton 1989b, Olsson et al. 2006) by leading discussions between the parties, bonding the group together, and bridging it with local water managers, in turn driving the scheme forward. The small size of the group is another relevant structural condition that would appear to have facilitated collective action. The LWT group is composed of 14 members, in comparison with several of the other groups, the largest of which, BAWAG, is composed of roughly 180 members and operates over a much wider geographic area.

The political-economic element of the framework draws attention to the IDB's relationship with the farmers and the EA. IDBs have a long history dating back to the medieval period, in which for much of this history they have shared a strong political and economic alliance with farmers and landowners (Purseglove 1988, Reeves and Williamson 2000). As a result, relatively high levels of trust exist between the IDB and farmers, a factor that was clearly of importance in the IDB's decision to take responsibility for administering the scheme. In the LWT case, it appears that the group of farmers was able to take advantage of this historic relationship to develop the scheme. In part, this is because the owner of one of the farms in the scheme was also an IDB board member.

Furthermore, we found evidence that the IDB was also well respected by the EA for its professionalism and technical knowhow. In this light, the IDB can be considered a "bridging organization," a role that is often crucial to comanagement arrangements because of its importance in building trust and social capital more generally, accessing and sharing knowledge, and resolving conflicts (Berkes 2009). It may also be argued that the LWT group itself performs some of the functions of a bridging organization within the scheme when seen in light of the relationship between its members and local water managers. Finally, with respect to the discourse element of the framework, it was clear during our interviews that particularly local EA staff, but also the farmers we spoke to, relied more on the compromise repertoire than we found when analyzing all but one of the other abstractor groups. The emergence of this repertoire reflects the development of trust among the farmers in the group, in which trust can be considered an emergent property that lowers transaction costs and helps to facilitate cooperation (Folke 2003, Olsson et al. 2004b).

As our analysis makes clear, much of LWT's involvement in collective-choice situations has occurred during the scheme's formation, when the system of rules that guides the operational activity of the group, the IDB, and the EA were put in place. This process of institution building helped to overcome low levels of trust while facilitating the emergence of power-sharing arrangements. Over time, the various mechanisms we identified previously, and in particular the carrot-and-stick mechanism, appear to have facilitated problem solving and social learning among group members in the face of change and uncertainty.
This was best illustrated when the group devised additional rules to fund the eradication of the potato brown rot virus from the drainage ditches that its members use for irrigation. The procedure was institutionalized in the members' protocol and demonstrates that the company structure was able to cope with an issue that was potentially divisive, given that some members did not grow potatoes and so faced much less of an incentive to expend resources treating the disease.

Considering the outcomes of the LWT scheme, from a transaction cost perspective it appears that information costs increase in some respects and decrease in others. In general terms, information costs go down as channels of communication open up between farmers, and between farmers and water managers, where local time-and-place knowledge is able to better complement the scientific knowledge held by the regulator. However, information costs also increase for farmers and the IDB with respect to the weekly submission and processing of water usage data. This level of communication is important not only in that it allows the IDB to correctly manage water levels, but because it endows the management system with greater sensitivity to both resource conditions and farmer decision making, meaning it is better prepared to deal with change when it occurs. Coordination costs also increased, especially in the early development phase as the group self-organized, legal costs for setting up the company were incurred, and rules and operating procedures were devised. It appears that these coordination costs are a significant factor in the group members' decision not to take the functionality of the scheme any further, given the pressurized economic environment that farmers are operating within, as well as their ideological leaning toward individualism and competition. We also found anecdotal evidence that an incentive for one or more group members to drop out was because they knew they could benefit from the additional water and better water level management that the scheme provided while avoiding the costs of being a member. This would represent a case of free riding, resulting in greater strategic costs.

Considering the overall evaluative criteria, we can conclude that the LWT scheme has enhanced the adaptability of local water governance in at least two ways. First, the establishment of new networks and improved channels of communication between farmers and water managers enhances the ability of the system to respond to social-ecological feedback in a more timely and flexible manner. Second, as demonstrated by the group's ability to deal with the case of potato brown rot virus, the organizational and institutional structure of the scheme has helped to develop greater social capital among participants and has facilitated their ability to solve problems when they arise. It is very unlikely that such an outcome to the threat of potato brown rot virus could have been achieved without the presence of the group. Therefore, despite a lack of interest in developing the scheme any further at present, it does appear that the institutional structure of the group and its relationship with the IDB and EA provide a latent capacity for further action and adaptation. Figure 7 illustrates the development of the various mechanisms we identify as they are triggered over the life span of the LWT comanagement scheme, in which the outcome is greater adaptive capacity at the local level.

The scheme has also enhanced economic efficiency because it allows specialist contract growers, an increasingly common 
feature of farming in England, more flexibility to rent land with water to grow and irrigate their crops anywhere across the whole land area of the group. This is a useful benefit considering the long crop rotations required for disease control for some of these crops. However, the scheme is unlikely to maximize economic efficiency because of the noncompetitive nature of the group's water allocation system. This sharing system prohibits members from bidding for water in such a way that, according to economic theory, it would go to its highest value use (Keohane and Olmstead 2007). It is, however, possible to conceive of a similar scheme that instead would adopt a competitive bidding system to allocate water.

Fig. 7. The evolution of mechanisms throughout the life span of the Lincoln Water Transfer Limited scheme.

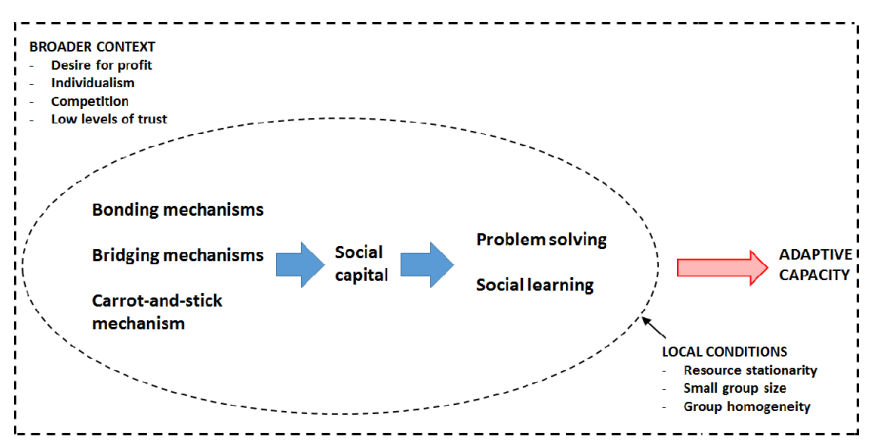

From a water use perspective, the scheme also appears to be more efficient than if each farmer held an individual abstraction license proportional to the farmer's current share of the group's joint license. This was demonstrated when the group's license came up for renewal in 2010. At that time, several of the members handed back some of their license share to the EA, resulting in a reduction to the overall license volume. The reason given for this was that these members felt confident that if they needed additional water they could apply for it within the group because of the added security the scheme provides. This mind-set differs from the standard situation in England, in which irrigators typically only use approximately half of their licensed volume but hold on to a large amount of "headroom" for security. Finally, as noted previously, the scheme demonstrated high levels of equity, in terms of fiscal equivalence, with financial costs to members being equivalent to the benefits they enjoyed in terms of license share. Again, this dynamic was institutionalized in the members' agreement and protocol.

\section{THE FINDINGS IN THE WIDER CONTEXT}

Of the factors of success and more abstract structural conditions and generative mechanisms identified in Table 2, the following will be taken further by considering their relevance in the context of water resources management in England: (1a) the stationarity of the resource; (1b) the formation of a limited company with a clearly defined and legally binding members' agreement and protocol; (1c) the role of the IDB as a bridging organization and scheme administrator; and (1d) a plus-sum game, in which the farmers involved have the opportunity to acquire additional water over and above their existing allocation.
Looking to the future, we can also make several informed inferences about changes to the exogenous variables of the framework. These are as follows: (2a) the biophysical-material world, for which water supply will become more variable and less secure, with water scarcity becoming more common (EA 2012); (2b) the rules-in-use, for which the regulatory system governing water resources will continue along a direction of increasing liberalization (DEFRA 2011, 2013b, EA/Ofwat 2011); and (2c) the political economy and discourse domain, for which there will be a continued drive toward both the use of economic instruments for managing the environment and natural resources and as the promotion of greater stakeholder participation and cooperation (DEFRA 2011, 2013a, 2013b).

How factors 1a-1d combine with inferences $2 a-2 c$ will be the subject of this discussion. We will also reflect on what our conclusions infer for comanagement in other countries with similar characteristics to those we have outlined.

Considering point 1a, the stationarity of the resource draws attention to the benefits of developing water storage in catchments where farmers currently abstract from nonstationary, free-flowing rivers. This would make decisions about resource allocation more predictable, in turn making it easier to devise cooperative arrangements (Ostrom et al. 1994, Schlager et al. 1994) akin to the LWT model. Furthermore, there is scope for enhancing the cooperative aspect of such an arrangement through the development of joint reservoir schemes nested within larger catchment-based abstractor groups. A small number of joint reservoir schemes already exist in the east of England and have allowed the farmers involved to devise their own operating procedures and allocation rules. Interestingly, in one case the three farm businesses have adopted the same shared strategy as LWT by forming a limited company. This company separately owns the reservoirs and related infrastructure, and the water is then sold back to the individual members, who have a holding right equivalent to their share of the business.

There are large parts of eastern England that, like the LWT scheme, are characterized by ponded networks of IDB-managed drainage ditches with a high degree of stationarity (Fig. 1). Furthermore, these regions tend to be prime agricultural land. This suggests that there is much scope for encouraging the emergence of water abstractor groups in these low-lying areas and provides an opportunity for IDBs to take on a new function as a bridging organization and administrator in a system of comanagement (1c). In recent years, the place of the IDBs as they currently exist has come under pressure from some angles (Purseglove 1988, Bankoff 2013), and a move such as this one might ensure their position within water management going forward.

It is also important to note that, particularly in the east of England, roughly $50 \%$ of abstraction is from groundwater sources (DEFRA 2015). Although water flow within aquifers is typically less predictable and controllable than the flow in ponded surface systems, here too there is potential for farmers to work together to allocate the resource among themselves. In all these cases, successful implementation of the scheme would be advanced by the formation of a limited company or similar legal structure and the adoption of a members' agreement and protocol (1b). As we 
have discussed previously, doing so provides a familiar and structured operating environment for farmers to work within and a system of rules that can reward a farm business with greater profit and business flexibility while formally penalizing rule transgressions. This in turn helps to overcome the relatively low levels of trust and a power dynamic that currently impedes the participation of farmers in cooperative forms of water governance.

As climatic conditions change and irrigation needs and water availability become more uncertain (2a), it is likely that these options for enhancing cooperation between farmer groups and water managers will become increasingly relevant if, as we suggest, they are able to enhance the adaptability and efficiency of the system. At the same time, as discussed previously, the possible emergence of a more liberalized licensing system also has the potential to change the relevance of these options from a comanagement perspective (2b). If we are to assume that the government continues with its current proposals to further develop a system of water rights trading in England, then in contrast to the present system in which water users hold a license that details a set quantity of water that may be abstracted, licenses might instead become linked to the available flow in a given water body. The volume of water linked to the license would therefore go up and down as conditions in the river or aquifer change, and some or all of the license could be traded with potential buyers. Agriculture holds by far that greatest number of abstraction licenses but only uses a small amount of water compared to the public water supply (approximately $1.5 \%$ to $50 \%$; DEFRA 2008). This dynamic points toward a future scenario in which many small trades occur between farmers, whereas less frequent but much larger trades occur between water companies, or between water companies and other sectors. Among other things, this has raised the issue of market power, in which it is feared that large abstractors, such as the water companies, will "outmuscle" the smaller abstractors in a water market.

This situation suggests that there is an opportunity to utilize the strategy of pooling water licenses and forming a company among a group of agricultural abstractors, in which doing so has the potential to increase their standing in the market. Our analysis of the other four case studies has already provided some evidence that abstractor groups have a tendency to facilitate trading by acting as a broker between buyers and sellers. By acting collectively, each member's license quantity would in effect serve as a share in the company. Here, as with the LWT scheme, fiscal equivalence could be achieved as member costs are incurred in proportion to their company share. Furthermore, participating in the market to secure additional water is a plus-sum game, which, as noted, provides a greater incentive for farmers to work together (1d). Having formed a company, members would have the option to trade their individual licenses internally, submitting any additional or unwanted water to a central pool, much like the procedure used by the LWT group. Alternatively, this internal allocation system could employ a competitive bidding/trading process to maximize economic efficiency. However, we caution that doing so has the potential to undermine other aspects of the arrangement (Frey and Jegen 1999, Cardenas et al. 2000), such as the development of social capital, in turn diminishing the adaptability of the system. Any of the central pool that is not taken up by members of the group may then be aggregated and traded with other players in the market. A collective approach such as this would have the advantage of providing flexibility of water use within the agricultural sector, while giving farmers greater security and a firmer standing in trading situations with bigger players in the market.

The UK government is currently only intending to develop water markets in those catchments in which trading would bring tangible benefits (DEFRA 2013b). In part, this is because instituting a new regulatory system is a resource-intensive process. This would suggest that, where possible, it would be better not to implement such changes if it can be avoided. Again, especially in the IDB-controlled ponded systems to the east of the country (Fig. 1), adopting schemes akin to the LWT model would save on the need to undertake wholesale changes, while bringing the range of potential benefits we identified. Developments of the sort outlined in this discussion fit well with the changing political and discursive landscape of environmental management in England, where there is an increasing move toward both greater participation and cooperation by all stakeholders in management decision making and action, as well as management liberalization through the adoption of economic measures such as water markets or payment for ecosystem services (2c).

It is probable that many of the findings that have made the LWT model successful would apply in other countries with a similar context. Generally speaking, these would be situations characterized by a history of centralized natural resource management, stakeholders embedded in capitalist systems of production who are driven by strong economic incentives to act individualistically and compete, and relationships lacking in trust. Although structural conditions like stationarity and storage, and mechanisms such as trust and a plus-sum game, are already established criteria in the literature on the collective management of natural resources (Ostrom et al. 1994, Dinar et al. 1997, Olsson et al. 2004a, Plummer 2006), far less attention has been given to institution building through the development of company structures. However, the subject has not been wholly neglected. For example, in a study of grazing systems in the Australian Outback, Brunckhorst and Marshall (2007) consider the benefits of developing a corporate approach among stakeholders as one option for collectively managing the resource. The authors note that "appropriate business structures might offer a supportive framework for collective decisions that facilitate adaptive management, [thus] enhancing sustainability and endurance" (Brunckhorst and Marshall 2007:182). Our analysis of the LWT scheme would support this assertion.

\section{CONCLUSION}

We have demonstrated the practical value of applying the politicized IAD framework to studies of comanagement, through an analysis of five farmer water abstractor groups in England. In this case, the critical or politicized component of the analysis assisted most in identifying the wider power dynamic that conditions the behavior of irrigators in lowland England. The research we have presented follows a previous submission to this journal, in which we explored the relationship between the politicized IAD framework and (adaptive) comanagement from a theoretical perspective. By adopting an integrated and critical approach, the analysis was able to identify a range of factors that appear to link water abstractor groups in lowland England to a comanagement outcome. 
These factors of success were also used to infer more abstract causal mechanisms and structural conditions that appeared to generate or facilitate the emergence and development of comanagement between abstractor groups and water managers. Perhaps of most relevance to explaining this outcome was the action of a carrot-and-stick mechanism, which relates to the particular set of legally binding rules that the group devised. Other mechanisms served to bond group members together and bridge them with local water managers, and resource stationarity was identified as the key structural condition facilitating the action of the mechanisms we identified. We discussed the relevance of several of our findings for English water governance in the future, wherein the framework guided a set of predictions about likely changes to the context in which water governance takes place. The discussion considered the relationship between comanagement and market theory by contemplating the place of water abstractor groups within a more liberalized system of water trading, a topic that has received scant attention in the literature to date.

In general, our findings have relevance for the emergence of comanagement in situations characterized by a power dynamic that promotes individualistic and competitive behavior and in which there has been a history of centralized and bureaucratic natural resource governance. In particular, we have found evidence that institution building through the adoption of a company structure with a well-defined, legally enforceable members' agreement and protocol can help to overcome low levels of trust among resource users and managers. Doing so has the potential to facilitate power-sharing arrangements in a way that enhances the adaptability of the system, while also maintaining or even improving its efficiency and equity.

The political economy and discourse analysis component of this investigation highlighted the need to encourage collective action among farmers through better integration of government programs and the channeling of funding sources. To this extent, we propose that the current system of grants and subsidies in England should be used to promote the formation of new catchment-based farmer groups, whose purpose is to comanage water resources, while bringing existing groups into the management fold. Funding for shared farm reservoirs could also be used to increase resource stationarity in catchments while creating a plus-sum game, with the intention of facilitating collective action. Finally, we conclude by suggesting that further investigations into the role of various types of company structures, as a means of facilitating stakeholder cooperation and participation in natural resource governance, would be of much interest to scholars and practitioners of comanagement.

\section{Responses to this article can be read online at:}

http://www.ecologyandsociety.org/issues/responses. php/7769

\section{Acknowledgments:}

The authors gratefully acknowledge the funding provided by the Engineering and Physical Science Research Council (EPSRC). This research is part of the EPSRC-funded project Transforming Water Scarcity through Trading (TWSTT), project reference EPI J005274/1.

\section{LITERATURE CITED}

Archer, M., R. Bhaskar, A. Collier, T. Lawson, and A. Norrie, editors. 1998. Critical realism: essential readings. Routledge, London, UK.

Armitage, D., F. Berkes, and N. Doubleday. 2007. Adaptive comanagement: collaboration, learning, and multi-level governance. University of British Columbia Press, Vancouver, British Columbia, Canada.

Armitage, D. R., R. Plummer, F. Berkes, R. I. Arthur, A. T. Charles, I. J. Davidson-Hunt, A. P. Diduck, N. C. Doubleday, D. S. Johnson, M. Marschke, P. McConney, E. W. Pinkerton, and E. K. Wollenberg. 2009. Adaptive co-management for socialecological complexity. Frontiers in Ecology and the Environment 7:95-102. http://dx.doi.org/10.1890/070089

Baland, J.-M., and J.-P. Platteau. 1996. Halting degradation of natural resources: is there a role for rural communities? Clarendon, Oxford, UK.

Bankoff, G. 2013. The "English Lowlands" and the North Sea Basin system: a history of shared risk. Environment and History 19:3-37. http://dx.doi.org/10.3197/096734013X13528328438992

Berkes, F. 2007. Adaptive co-management and complexity: exploring the many faces of co-management. Pages 19-37 in D. Armitage, F. Berkes, and N. Doubleday, editors. Adaptive comanagement: collaboration, learning, and multi-level governance. University of British Columbia Press, Vancouver, British Columbia, Canada.

Berkes, F. 2009. Evolution of co-management: role of knowledge generation, bridging organizations and social learning. Journal of Environmental Management 90(5):1692-1702. http://dx.doi. org/10.1016/j.jenvman.2008.12.001

Bhaskar, R. 1975. A realist theory of science. Harvester, Sussex, UK.

Bhaskar, R. 1979. The possibility of naturalism: a philosophical critique of contemporary human sciences. Harvester, Brighton, UK.

Brunckhorst, D., and G. Marshall. 2007. Designing robust common property regimes for collaboration towards rural sustainability. Pages 179-207 in A. Smajgl and S. Larson, editors. Sustainable resource use: institutional dynamics and economics. Earthscan, London, UK.

Cardenas, J. C., J. Stranlund, and C. Willis. 2000. Local environmental control and institutional crowding-out. World Development 28(10):1719-1733. http://dx.doi.org/10.1016/s0305-750x (00)00055-3

Clement, F. 2010. Analysing decentralised natural resource governance: proposition for a "politicised" institutional analysis and development framework. Policy Sciences 43:129-156. http:// dx.doi.org/10.1007/s11077-009-9100-8

Danermark, B., M. Ekstrom, L. Jakobsen, and J. Karlsson. 2002. Explaining society: critical realism in the social sciences. Routledge, New York, New York, USA.

Davies, B., and R. Harré. 1990. Positioning: the discursive production of selves. Journal for the Theory of Social Behaviour 20(1):43-63. http://dx.doi.org/10.1111/j.1468-5914.1990.tb00174. $\underline{\mathrm{x}}$ 
Department for the Environment, Food, and Rural Affairs (DEFRA). 2008. Future water: the government's water strategy for England. The Stationery Office, Norwich, UK. [online] URL: https:/www.gov.uk/government/uploads/system/uploads/attachment data/ file/69346/pb13562-future-water-080204.pdf

Department for the Environment, Food, and Rural Affairs (DEFRA). 2011. The natural choice: securing the value of nature. The Stationery Office, Norwich, UK. [online] URL: https://www. gov.uk/government/uploads/system/uploads/attachment data/ file/228842/8082.pdf

Department for the Environment, Food, and Rural Affairs (DEFRA). 2012. Agriculture in the United Kingdom 2012. DEFRA, London, UK. [online] URL: https://www.gov.uk/ government/uploads/system/uploads/attachment data/file/208436/ auk-2012-25jun13.pdf

Department for the Environment, Food, and Rural Affairs (DEFRA). 2013a. Catchment based approach: improving the quality of our water environment. A policy framework for encouraging the wider adoption of an integrated catchment based approach to improving the quality of our water environment. DEFRA, London, UK. [online] URL: https://www.gov.uk/ government/uploads/system/uploads/attachment_data/file/204231/ pb13934-water-environment-catchment-based-approach.pdf

Department for the Environment, Food, and Rural Affairs (DEFRA). 2013b. Making the most of every drop: consultation on reforming the water abstraction management system. DEFRA, London, UK. [online] URL: https://consult.defra.gov.uk/water/ abstraction-reform/supporting_documents/abstractionreformconsultcondoc20131217.pdf

Department for the Environment, Food, and Rural Affairs (DEFRA). 2015. Observatory monitoring framework - indicator data sheet. Environmental impact: water. DEFRA, London, UK. [online] URL: https://www.gov.uk/government/uploads/system/ uploads/attachment data/file/270336/agindicator-da5-09jan14.pdf

Dinar, A., M. W. Rosegrant, and R. Meinzen-Dick. 1997. Water allocation mechanisms, principles, and examples. Policy Research Working Papers. World Bank, Washington, D.C., USA. http://dx. doi.org/10.1596/1813-9450-1779

Easton, G. 2010. Critical realism in case study research. Industrial Marketing Management 39(1):118-128. http://dx.doi.org/10.1016/ j.indmarman.2008.06.004

Edley, N. 2001. Analysing masculinity: interpretive repertoires, ideological dilemmas, and subject positions. Pages 189-228 in M. Wetherell, S. Taylor, and S. J. Yates, editors. Discourse as data: a guide for analysis. Sage, London, UK.

Environment Agency (EA). 2012. The case for change - current and future water availability. EA, Bristol, UK. [online] URL: http://www.wildtrout.org/sites/default/files/library/Water $\% 20$ Situation $\%$ 20report $\% 20 \mathrm{EA} \% 20$ March $\% 202012$.pdf

Environment Agency (EA). 2013. Water for life and livelihoods. England's waters: challenges and choices. EA, Bristol, UK. [online] URL: https://consult.environment-agency.gov.uk/file/2535403

Environment Agency (EA)/Ofwat. 2008a. Exploring views on the potential for more active water rights trading. Ofwat, Birmingham,
UK. [online] URL: http://www.ofwat.gov.uk/competition/ review/pap_rsh_syndovatedec08.pdf

Environment Agency (EA)/Ofwat. 2008b. Review of barriers to water rights trading: final report February 2009. Ofwat, Birmingham, UK. [online] URL: http://www.ofwat.gov.uk/ competition/review/pap pos waterrightstrad.pdf

Environment Agency (EA)/Ofwat. 2011. The case for changereforming water abstraction management in England. Ofwat, Birmingham, UK. [online] URL: http://www.ofwat.gov.uk/ future/markets/waterrights/pap pos20111205abstraction.pdf

Folke, C. 2003. Freshwater for resilience: a shift in thinking. Philosophical Transactions of the Royal Society of London B: Biological Sciences 358:2027-2036. http://dx.doi.org/10.1098/ rstb.2003.1385

Folke, C., T. Hahn, P. Olsson, and J. Norberg. 2005. Adaptive governance of social-ecological systems. Annual Review of Environment and Resources 30:441-473. http://dx.doi.org/10.1146/ annurev.energy.30.050504.144511

Frey, B. S., and R. Jegen. 1999. Motivation crowding theory: a survey of empirical evidence. Working Paper No. 26. Institute for Empirical Research in Economics, University of Zurich, Zurich, Switzerland. [online] URL: http://clivespash.org/speer/iewwp026. pdf

Gaventa, J. 2005. Reflections on the uses of the "power cube" approach for analyzing the spaces, places and dynamics of civil society participation and engagement. MFP Breed Network, The Netherlands. [online] URL: http://www.participatorymethods. org/sites/participatorymethods.org/files/reflections_on_uses_powercube. pdf

Gaventa, J. 2006. Finding the spaces for change: a power analysis. IDS Bulletin 37:23-33. http://dx.doi.org/10.1111/j.1759-5436.2006. $\underline{\mathrm{tb} 00320 . \mathrm{x}}$

Hajer, M. A. 1995. The politics of environmental discourse: ecologicalmodernization and the policy process. Oxford University Press, Oxford, UK.

Harré, R., F. M. Moghaddam, T. P. Cairnie, D. Rothbart, and S. R. Sabat. 2009. Recent advances in positioning theory. Theory \& Psychology 19(1):5-31. http://dx.doi.org/10.1177/0959354308101417

Holderness, B. A. 1985. British agriculture since 1945. Manchester University Press, Manchester, UK.

Holman, I. P., and P. Trawick. 2011. Developing adaptive capacity within groundwater abstraction management systems. Journal of Environmental Management 92(6):1542-1549. http://dx.doi. org/10.1016/j.jenvman.2011.01.008

Imperial, M. T. 1999. Institutional analysis and ecosystem-based management: the institutional analysis and development framework. Environmental Management 24(4):449-465. http://dx. doi.org/10.1007/s002679900246

Keohane, N. O., and S. M. Olmstead. 2007. Markets and the environment. Island, Washington, D.C., USA.

Kiser, L., and E. Ostrom. 1982. The three worlds of action: a metatheoretical synthesis of institutional approaches. Pages 
179-222 in E. Ostrom, editor. Strategies of political enquiry. Sage, Beverly Hills, California, USA.

Knox, J., P. Trawick, B. Leathers, J. Rodriguez-Diaz, and M. Kay. [date unknown]. Working together to protect water rights. UK Irrigation Association, Rushden, Northamptonshire, UK. [online] URL: http://www.ukia.org/pdfs/Working\%20together. pdf

Leathes, W., J. W. Knox, M. G. Kay, P. Trawick, and J. A. Rodriguez-Diaz. 2008. Developing UK farmers' institutional capacity to defend their water rights and effectively manage limited water resources. Irrigation and Drainage 57(3):322-331. http://dx.doi.org/10.1002/ird.436

Lukes, S. 1974. Power: a radical view. Macmillan, London, UK.

Marsden, T., J. Murdoch, P. Lowe, R. Munton, and A. Flynn. 1993. Constructing the countryside. University College London Press, King's Lynn, UK.

Moberg, F., and V. Galaz. 2005. Resilience: going from conventional to adaptive freshwater management for human and ecosystem compatability. Swedish Water House Policy Brief No. 3. Stockholm International Water Institute, Stockholm, Sweden. [online] URL: http://www.siwi.org/documents/Resources/Policy_Briefs/ PB3 Resilience 2005.pdf

Olsson, P., C. Folke, and F. Berkes. 2004a. Adaptive comanagement for building resilience in social-ecological systems. Environmental Management 34(1):75-90. http://dx.doi. org/10.1007/s00267-003-0101-7

Olsson, P., C. Folke, and T. Hahn. 2004b. Social-ecological transformation for ecosystem management: the development of adaptive co-management of a wetland landscape in southern Sweden. Ecology and Society 9(4): 2. [online] URL: http://www. ecologyandsociety.org/vo19/iss4/art2/

Olsson, P., L. H. Gunderson, S. R. Carpenter, P. Ryan, L. Lebel, C. Folke, and C. S. Holling. 2006. Shooting the rapids: navigating transitions to adaptive governance of social-ecological systems. Ecology and Society 11(1): 18. [online] URL: http://www. ecologyandsociety.org/vol11/iss1/art18/

Ostrom, E. 1990. Governing the commons: the evolution of institutions for collective action. Cambridge University Press, Cambridge, UK. http://dx.doi.org/10.1017/cbo9780511807763

Ostrom, E. 2005. Understanding institutional diversity. Princeton University Press, Princeton, New Jersey, USA.

Ostrom, E. 2011. Background on the institutional analysis and development framework. Policy Studies Journal 39(1):7-27. http:// dx.doi.org/10.1111/j.1541-0072.2010.00394.x

Ostrom, E., R. Garderner, and J. Walker. 1994. Rules, games, and common-pool resources. University of Michigan Press, Ann Arbor, Michigan, USA.

Pinkerton, E., editor. 1989a. Co-operative management of local fisheries: new directions for improved management \& community development. University of British Columbia Press, Vancouver, British Columbia, Canada.

Pinkerton, E. 1989b. Introduction: attaining better fisheries management through co-management-prospects, problems, and propositions. Pages 3-36 in E. Pinkerton, editor. Co-operative management of local fisheries: new directions for improved management \& community development. University of British Columbia Press, Vancouver, British Columbia, Canada.

Plummer, R. 2006. Sharing the management of a river corridor: a case study of the comanagement process. Society \& Natural Resources: An International Journal 19(8):709-721. http://dx.doi. org/10.1080/08941920600801132

Plummer, R. 2009. The adaptive co-management process: an initial synthesis of representative models and influential variables. Ecology and Society 14(2): 24. [online] URL: http://www. ecologyandsociety.org/vol14/iss2/art24/

Plummer, R., and D. Armitage. 2007. Crossing boundaries, crossing scales: the evolution of environment and resource comanagement. Geography Compass 1(4):834-849. http://dx.doi. org/10.1111/j.1749-8198.2007.00040.x

Plummer, R., and J. Fitzgibbon. 2007. Connecting adaptive comanagement, social learning, and social capital through theory and practice. Pages 38-61 in D. Armitage, F. Berkes, and N. Doubleday, editors. Adaptive co-management: collaboration, learning, and multi-level governance. University of British Columbia Press, Vancouver, British Columbia, Canada.

Polski, M. M., and E. Ostrom. 1999. An institutional framework for policy analysis and design. Working Paper W98-27. Indiana University, Bloomington, Indiana, USA. [online] URL: https:// mason. gmu.edu/ mpolski/documents/PolskiOstromIAD.pdf

Pomeroy, R. S., and F. Berkes. 1997. Two to tango: the role of government in fisheries co-management. Marine Policy 21 (5):465-480. http://dx.doi.org/10.1016/s0308-597x(97)00017-1

Potter, J., and M. Wetherell. 1987. Discourse and social psychology: beyond attitudes and behaviour. Sage, London, UK.

Purseglove, J. 1988. Taming the flood: a history and natural history of rivers and wetlands. Oxford University Press, Oxford, UK.

Reeves, A., and T. Williamson. 2000. Marshes. Pages 150-168 in J. Thirsk, editor. Rural England: an illustrated history of the landscapes. Oxford University Press, Oxford, UK.

Rose, C. M. 2002. Common property, regulatory property, and environmental protection: comparing community-based management to tradable environmental allowances. Pages 233-258 in E. Ostrom, T. Dietz, N. Dolsak, P. C. Stern, S. Stonich, and E. U. Weber, editors. The drama of the commons. National Academies, Washington, D.C., USA.

Sayer, A. 1992. Method in social science. Second edition. Routledge, London, UK.

Schlager, E., W. Blomquist, and S. Y. Tang. 1994. Mobile flows, storage, and self-organized institutions for governing commonpool resources. Land Economics 70(3):294-317. http://dx.doi. org/10.2307/3146531

Tietenberg, T. 2002. The tradable permits approach to protecting the commons: what have we learned? Pages 197-232 in E. Ostrom, T. Dietz, N. Dolšak, P. C. Stern, S. Stonich, and E. U. Weber, editors. The drama of the commons. National Academies, Washington, D.C., USA. 
United Nations Environment Programme (UNEP). 2012. Global environment outlook 5: environment for the future we want. UNEP, Nairobi, Kenya. [online] URL: http://www.unep.org/geo/pdfs/ geo5/GEO5 FrontMatter.pdf

Venables, J., D. Sisson, I. Moodie. [date unknown]. A vision for internal drainage boards in England and Wales. Association of Drainage Authorities, Stoneleigh Park, Warwickshire, UK.

VeneKlasen, L., and V. Miller. 2002. A new weave of power, people and politics: the action guide for advocacy and citizen participation. World Neighbors, Oklahoma City, Oklahoma, USA.

Wade, R. 1987. The management of common property resource: collective action as an alternative to privatisation or state regulation. Cambridge Journal of Economics 11:95-106.

Weatherhead, E. K. 2006. Survey of irrigation of outdoor crops in 2005: England and Wales. Cranfield University, Cranfield, UK.

Whaley, L., and E. K. Weatherhead. 2014. An integrated approach to analyzing (adaptive) co-management using the "politicized" IAD framework. Ecology and Society 19(1): 10. http://dx.doi.org/10.5751/ES-06177-190110

Whaley, L., and E. K. Weatherhead. 2015a. Competition, conflict, and compromise: three discourses used by irrigators in England and their implications for the co-management of water resources. Water Alternatives 8(1):800-819.

Whaley, L., and E. K. Weatherhead. 2015b. Power sharing in the English lowlands? The political economy of farmer participation and cooperation in water governance. Water Alternatives 8 (1):820-843.

Wilson, D. C. 2010. Considering critical dualism: a response to Fikret Berkes. Mast 9(1):51-54.

Woods, A. 2000. Agriculture: sustainable business - sustainable environment? Water and Environmental Journal 14(2):94-98. http://dx.doi.org/10.1111/j.1747-6593.2000.tb00233.x

Yin, R. K. 2009. Case study research: design and methods. Sage, Thousand Oaks, California, USA. 